\title{
ЕПІЗООТОЛОГІЧНІ ТА ЕПІДЕМІОЛОГІЧНІ АСПЕКТИ КИШКОВОГО ІЄРСИНІОЗУ В УКРАЇНІ (ОГЛЯД)
}

\author{
Труба Ольга Олексіївна \\ магістр ветеринарної медицини \\ Сумський національний аграрний університет, м. Суми, Україна \\ ORCID: 0000-0001-5544-5902 \\ olga.tryba93@gmail.com
}

Стаття містить аналітичні відомості про сучасний епідеміологічний стан поширення кишкового ієрсиніозу серед тварин і людей як за кордоном, так і в Україні.

На підставі аналізу національних і закордонних наукових джерел у статті представлено інформацію щодо поширення ієрсиніозу серед людей і тварин. Охарактеризовано сучасні підходи до ідентифікації патогенних итамів. Проведено огляд інформації і порівняльну характеристику методів виявлення і дослідження Yеrsinia enterocolitica. Встановлено наявні нині методи дифреренціації патогенних і непатогенних штамів Y.enterocolitica різних сероварів, які можна умовно поділити на 4 групи: біологічні, генетичні, фенотипічні, імунологічні. Базуючись на отриманих даних і власному дослідженні, можна стверджувати, що найбільш достовірні результати досліджень можна отримати, використовуючи тільки повну комбінацію методів. Під час аналізу показників визначено головні серовари збудника кишкового ієрсиніозу, які є патогенними як для людей, так і для тварин. На основі аналізу літературних джерел в останні роки територію України можна умовно поділити на області, що відповідають трьом рівням ураження: низькому, середньому і високому. Низький рівень захворюваності встановлюють у разі виявлення від 0,01 до 0,11\% випадків на 100 тисяч населення, середній рівень - 0,12-0,58\% випадків на 100 тисяч населення, високий рівень - 0,59\% спалахів і вище на 100 тисяч населення.

Хоча Yersinia enterocolitica $є$ загальним ентеропатогеном, який зазвичай спричинює відносно легкий перебіг хвороби, проте він може бути основною причиною небезпечної для життя інфекції, що виникає після гемотрансфузії, спричиняючи сепсис, а також може призводити до тяжких постінфекційних ускладнень, таких як артрит.

Унаслідок здійснення власних досліджень установлено, що одним із досить простих, економічно доцільних та інфрормативних методів діагностики ієрсиніозу у котів є посів на ієрсиніозне поживне середовище, на якому бактеріальна культура росте досить швидко і специфічно.

Із використанням літературних джерел проведено вибірку основних комплексів дослідження Yersinia enterocolitica. Проведено економічну оцінку їх застосування. Піднято питання про біологічну безпеку людини і дрібних домашніх тварин щодо поширення збудника кишкового ієрсиніозу.

Ключові слова: кишковий ієрсиніоз, діагностика, епізоотологія, патологія, Yersinia enterocolitica, контамінація, дрібні домашні тварини, захворюваність.

DOI https://doi.org/10.32845/bsnau.vet.2021.3.7

Вступ. За останні роки все частіше з'являється інсрормація про випадки виникнення кишкового ієрсиніозу як серед людей, так і серед тварин, але основних причин виникнення і дослідження таких спалахів описано мало.

Кишковий ієрсиніоз - гостре антропозоонозне захворювання, для якого характерно ураження шлунково-кишкового тракту, а також виникнення артритів, безпліддя у самок, септікопіємії.

Збудником хвороби є Yersinia enterocolitica. Основний шлях передачі збудника - аліментарний. Хвороба у молодняка тварин триває гостро із симптомами діареї та ураженням нервової системи, нерідко із летальними випадками. У зрілих особин хвороба може перебігати безсимптомно досить тривалий проміжок часу, тварина може залишатися носієм інфекції (Babkin A.F., Ivanovska L.B..2005, Vasylev D.A., Zolotukhyn S.N., Pomerantsev D.A., 2003, Shevchenko A.A. .2013).

Y. enterocolitica часто виділяли у диких тварин (кабанів, лисиць, косуль, птахів ) і худоби (наприклад овець, великої рогатої худоби, кіз і птиці), але одним із основних резервуарів для зараження людей вважають свиней, від яких патогенні штами Y.enterocolitica (зокрема серотипи О: 3 та О: 9) можуть виділятися регулярно. Свині зазви- чай $є$ безсимптомними носіями, але вони демонструють чітку сероконверсію (виробляють антитіла проти білків та ліпополісахаридів) (N.O.Holovachova, 2008; L.B. Ivanovska, 2007; A. V. Ushkalov, 2013). Резервуаром штамів Y. Enterocolitica у США та в Європі вважають саме свиней (V.Thibodeau, E.H. Frost, S. Quessy, 2001; B. Nielsen, C. Heisel, A. Wingstrand, 1996). Але заразитися можна і від домашніх улюбленців контактним шляхом. Як стверджує Е. В. Радзинська (2013), хвора людина не несе загрози для оточуючих, проте залишається бактеріоносієм до 4 місяців після одужання на відміну від домашніх тварин, які, будучи умовно здоровими, можуть передавати інфекцію іншим особинам із першого дня ії виникнення. Деякі види тварин можуть до кінця життя бути бактеріоносіями.

Водночас D.J. Hetem (2013) описує передачу Y.enterocolitica від домашньої собаки до однорічного немовляти в Іспанії. Ідентифікація бактерій і тест на чутливість Vitek-2 підтвердили позитивний результат ПЛР sз ідентифікацією Y enterocolitica. Надалі був проведений аналіз аглютинації, який показав серотип O : 3. Після кількатижневої діареї на фекаліях була проведена ПЛР-детекція ентеропатогенних бактерій, яка виявила Y enterocolitica. Повторно досліджені культури дали 
Yenterocolitica біотип 4, серотип B: 3 у фекаліях дівчинки, а також цуценя. Незважаючи на лікування антибіотиками, симптоми і виділення організму із фекаліями зберігалися протягом 2 місяців. Висів проб фекалій дівчинки і тварини на агар CIN призводив до росту схожих безбарвних колоній. Ізольовані культури від дитини і цуценя були досліджені у референтній лабораторії Нідерландів за допомогою імпульсного польового гель-електрофорезу (PFGE), які на 95\% підтвердили їхню схожість за PFGE Y enterocolitica біотипу 4, серотипу 0:3. Однак обидва штами не змогли гідролізувати целобіозу, на що здатні 90\% Ү-ентероколітичного біотипу 4. Ця інформація разом із однаковим біотипом і серотипом показала велику ймовірність спорідненості ізольованих штамів (D.J. Hetem, M. Pekelharing, S.F. Thijsen).

В Україні дослідженню кишкового ієрсиніозу тварин досі приділяється мало уваги. Залишається відкритою досить значна кількість питань із епізоотології, діагностики, лікування і профілактики кишкового ієрсиніозу. Нині існує обмежена кількість відомостей щодо діагностики і лікування тварин, хворих на ієрсиніоз, спричинений різними сероварами Yersinia enterocolitica (S. A. Aleksych, Shtaihervalt, Dzh. Bokemul, 1987; Kh. Berkove, A.H. Shtaihervalt,1984; H.la.Tseneva, 2001).

Не досліджено ймовірність гемотранфузіонального шляху передачі збудника, а також залежність тяжкості перебігу захворювання від здатності бактерій колонізувати кишковий тракт різноманітних господарів.

Мета роботи - аналіз наявних повідомлень про сучасну епізоотологію і епідеміологію кишкового ієрсиніозу в Україні.

Матеріали та методи дослідження. Матеріалами дослідження слугували опубліковані наукові роботи із цієї проблеми та повідомлення Державної санітарно-епідеміологічної служби і Держспоживслужби. Ефективність методів діагностики цього захворювання визначали на підставі аналізу літературних джерел (як вітчизняних, так і закордонних).

Результати досліджень. Кишковий ієрсиніоз реєструється на всій земній кулі. Найбільше згадувань у літературі США, Європи та Азії, Японії. Він має значне поширення як серед тварин, так і серед людей (H. la.Tseneva, 2001; V.V. Makarov, 2008; Julia Schaake, 2013).

На території України санітарно-епідеміологічна служба вперше зареєструвала ієрсиніоз у 1986 році. Аналіз літературних джерел свідчить, що в Україні спалахи захворювання на кишковий ієрсиніоз реєстрували практично на всій території країни (H.S. Holovchak, 2000; L. B. Ivanovska, 2007; A.V. Ushkalov, 2013).

Нині територію України можна розділити на три зони: у першій досить рідко фіксуються спалахи захворювання (від 0,01 до 0,11\% випадків на 100 тисяч населення), наприклад, Волинська, Сумська, Миколаївська, Тернопільська, Хмельницька, Чернівецька, Кіровоградська, Черкаська, Полтавська, Житомирська, Закарпатська, Івано-Франківська, Львівська, Чернігівська; у другій зоні відсоток захворюваності досягає 0,58\% випадків на 100 тисяч населення, причому така ситуація простежується у Вінницькій, Дніпропетровській, Донецькій,
Київській, Луганській, Рівненській, Херсонській областях, а також у столиці; третя зона із найбільшим відсотком хворих (від 0,59\% випадків і вище на 100 тисяч населення): Харківська, Запорізька та Одеська області (A. V. Ushkalov, 2013).

Аналіз наявних даних свідчить про те, що кишковий ієрсиніоз поширений серед різних видів домашніх тварин і людини та не залежить від віку і статі. Найчастіше збудника ієрсиніозу виділяють із ґрунту, води, різних харчових продуктів. Представники виду Y. enterocolitica широко поширені у природі через те, що вони добре пристосовані до сапрофітного існування. Це $є$ однією із характерних біологічних властивостей цього збудника і забезпечує його існування як біологічного виду. Зокрема, В.О. Доценко, Н.О. Головачова (2006) відносять ієрсиніози до сапрозоонозів - групи інфекцій, збудники яких тісно пов'язані як із навколишнім середовищем, так і з організмом теплокровних. Між цими екологічними нішами відбувається безперервна циркуляція збудника. Характерними особливостями збудників сапрозоонозів $€$ їхня психрофрільність і значна термотолерантність, що має дуже важливе значення (Dotsenko, Holovachova, Simonovych et al., 2006; Holovachova, 2008).

Поряд із сапрофітними властивостями цей мікроорганізм проявляє і паразитичні ознаки завдяки факторам патогенності з використанням адгезивності, інвазивності, здатності протистояти фагоцитозу в організмі теплокровних тварин (Berkove, A. Shtaihervalt, A. Hyiul, H. KhantlyKarter, D. D. Brenner, 1984; Aleksych, Shtaihervalt, Bokemul, Khantly-Karter, Brenner,1987).

Збудник Y. enterocolitica був виділений практично в усіх видів тварин: птахів, ссавців, риб, земноводних, молюсків, комах і людей, навіть у мух (Kavruk, Shumylov, Melnychenko, 2005; Karetkyna, lushchuk, 1999; Lenchenko, 2006).

Вітчизняними науковцями виявлено і вивчено циркуляцію збудника у різних тварин, зокрема встановлено поширення сероварів Yersinia enterocolitica 0:3, 0:6, 0:9 у свиней; у птиці - 0:9 (Lenchenko, 2006; Smyrnov, 2004).

Закордонними науковцями проведено специфічні дослідження щодо здатності бактерій колонізувати кишковий тракт різноманітних господарів-ссавців та їхньої бактеріологічної здатності спричинювати різного ступеня тяжкості захворювання в окремих господарів. Для аналізу і порівняння окремих детермінантів вірулентності, що сприяють колонізації та індукції імунної відповіді у різних господарів, досліджено взаємодію різних ізолятів серотипів, отриманих від людей і тварин, а саме: О:3, О:5,27, 0:8, О:9 із мишачими.

Зокрема, Джулія Шаке (Dzhuliia Shake, 2013) із колегами описують залежність тяжкості перебігу захворювання від здатності бактерій до колонізації кишкового тракту ссавців. У своїх дослідженнях науковці виявили взаємодію між різними серотипами ізолятів Yersinia enterocolitica 0:3, 0:8, О:9, отриманих від людей і тварин, з ентероцитами і макрофрагами мишей, свиней та людей і встановили, що у різноманітності виживання і реплікації у макрофрагах, а також в індукованій протизапальній реакції існують відмінності, про що свідчить специфічна імунна відповідь, характерна для кожного господаря. 
Окремі автори, такі як В.О. Доценко, Н. О. Головачова, у своїх працях указують на «відношення ієрсиніозів до сапрозоонозів - групи інфекцій, збудники яких тісно пов'язані як із навколишнім середовищем, так і 3 організмом теплокровних. Між цими екологічними нішами відбувається безперервна циркуляція збудника. Характерними особливостями збудників сапрозоонозів $€$ їхня психрофільність і значна термотолерантність, що має дуже важливе значення» (Dotsenko, Holovachova, Simonovych et al., 2006; Holovachova, 2008).

Слід звернути увагу на те, що ієрсиніозна інфекція також $€$ небезпечним зооантропонозом. Адже за безсимптомного перебігу хвороби персистенція збудників, приховане існування і поширення інфекції призводять до маніфрестуючих її проявів, а використання продуктів тваринництва у цьому випадку є основним чинником виникнення харчових токсикоінфекцій людей (Sydorchuk, 2007; EFSA, 2007).

Гуманна медицина визначає ієрсиніоз як харчову інфекцію, не беручи до уваги той факт, що одним із шляхів передачі можуть бути домашні тварини, а саме коти і собаки.

Факторами передавання збудника ієрсиніозної інфекції до людини є сільськогосподарська продукція як тваринницького, так і рослинного походження (Hyne, Karnyel, Leklerk; Andreoletti, Budka, Buncic, 2007). Важливим буде згадати, що Y. Enterocolitica був виділений із сирого молока у багатьох країнах, а саме в Австралії, Канаді, Чехії та США (Nielsen, Heisel, Wingstrand, 1996). Згідно з оприлюдненими даними Європейського відомства із безпеки харчових продуктів (EFSA), у Норвегії виявлено випадки контамінації салатів патогенними для людини збудниками кишкового ієрсиніозу. Ці дані отримані завдяки молекулярно-генетичним методам дослідження, які, на жаль, не застосовуються у нашій країні (Berkove, 2019). Досить часто у літературних джерелах з'являється інформація про зараження Y. Enterocolitica устриць, мідій та інших морепродуктів, а також салатів із курки, грибів, свіжої капусти, селери і моркви. Дослідження в Іспанії показало, що 76,5\% курячих тушок було контаміновано ієрсиніями (Lenchenko, 2006). У більшості випадків установлено забруднення ієрсиніями: свинячий язик (83\%), печінка (73\%), серце (71\%) і нирки (67\%). Основним джерелом контамінації продуктів харчування ієрсиніями є органи ротової порожнини (язик, мигдалики), контаміновані майже у $50 \%$ зафіксованих випадків (V. Thibodeau, E. H. Frost, S. Quessy, 2001). Статистичні дані щодо виділення і типізації ізолятів Y. enterocolitica із м'яса і субпродуктів свиней свідчать про те, що у 43,4\% виявлено збудника, 42, 2\% ізолятів яких припадало на серотип 0:3; 1,1\% - на серотипи O:8 і О:9. Досліджено та описано 623 проби, в яких із мигдаликів ізольовано 62,2\% ієрсиній, із них 59,6\% віднесено до серотипу 0:3. Зі 150 проб субпродуктів у 45,4\% випадків було ізольовано збудника серотипу 0:3 (RosaCapita*CarlosAlonso-CallejaMiguelPrietoMaría del CaminoGarcía-FernándezBenitoMoreno 2002).

Хоча Yersinia enterocolitica є загальним ентеропатогеном, який зазвичай спричинює відносно легкий перебіг хвороби, проте він, за даними Françoise Guinet, Elisabeth Carniel, Alexandre Leclercq (2011), є основною причиною небезпечної для життя інфекції, що виникає після гемотрансфузії, спричиняючи сепсис, який стає найчастішим інфекційним ускладненням під час переливання крові, оскільки психротрофна Y. Enterocolitica не пригнічується за температури зберігання цільної крові та концентрату еритроцитів $\left(2-6^{\circ} \mathrm{C}\right)$. Розмноження бактерій підтримується глюкозою та аденином (джерелами енергії і вуглецю для ієрсиній), які є складниками розчинів антикоагулянтів-консервантів і добавок (F. Guinet, E. Carniel, A. Leclercq, 2011). Концентрати еритроцитів готують за $\mathrm{pH} 7,3$, що знаходиться у межах оптимального діапазону (7-8) для росту Y. Enterocolitica (A. Rahman, T. S. Bonny, S. Stonsaovapak and C. Ananchaipattana; Md. L. Bari, M. A. Hossain, K. Isshiki and Dike Ukuku, 2011). На підставі цього можна стверджувати, що гемотрансфузія $€$ ще одним шляхом передавання збудника ієрсиніозу.

Вітчизняними дослідниками проведено значну роботу з ізоляції Y. enterocolitica із різних видів сільськогосподарських тварин, вивчено їхні біологічні властивості; розроблено і запропоновано досить специфічні засоби серологічної діагностики кишкового ієрсиніозу у тварин, які були спровоковані сероварами 0:3, 0:6.30 та 0:9 (Babkin, Ivanovska, 2005; Vasylev, Zolotukhyn, Pomerantsev, 2003; Dotsenko, Holovachova, Simonovych, 2006). Окрім того, отримано відомості про антибіотикорезистентність циркулюючих сероварів збудника, на основі яких змодульовані та запропоновані схеми лікування хворого поголів'я у господарствах різного типу (Kavruk, Shumylov, Melnychenko, 2005; Sydorchuk, 2007; Tseneva, 2001).

Однак лабораторна діагностика ієрсиніозу донині потребує вдосконалення і розроблення нових сучасних засобів ідентифікації збудника. Досить важливим чинником якісної діагностики є своєчасна і правильна доставка патологічного матеріалу до лабораторії. Термін транспортування дослідного матеріалу не повинен перевищувати 12 годин із моменту відбору, фрекалій не пізніше 4 годин, причому транспортують на акумуляторах холоду у спеціально обладнаних термосумках або в переносних холодильниках. У разі неможливості своєчасної та якісної доставки досліджуваний матеріал направляється у замороженому вигляді або консервованому у 30 \%-му водному розчині гліцерину або в 1\% розчині фоормаліну (Shevchenko, 2013).

Для прижиттєвої діагностики ієрсиніозів до лабораторії відправляють останні порції фекалій тварин, слизові і кровяні виділення, а також проби крові. Посмертно досліджують підщелепні і заглоткові лімфатичні вузли, корінь язика, мигдалики, зрізи з уражених паренхіматозних органів, ділянки тонкого і товстого відділів кишечнику, особливо ділянки некротичних вогнищ (за умови невикористання антимікробних препаратів), змиви із прямої кишки, а також свіжі трупи дрібних домашніх тварин, риби, гризунів і птахів (Vasylev, Zolotukhyn, Pomerantsev, 2003; Shevchenko, 2013; Dotsenko, Holovachova, Simonovych, 2006). Перед посівом на поживне середовище рекомендується провести його «збагачення» задля підвищення ефективності росту культур ієрсиній. У таких випадках 
загальновизнаним $є$ метод «холодового збагачення», який базується на здатності ієрсиній рости на поживних субстратах за умов низьких позитивних температур. Переважна більшість інших мікроорганізмів не має такої здатності. Основна особливість Y. Enterocolitica - це здатність розмножуватися на «голодних» середовищах. Задля їх створення використовують фосфратно-буферний розчин як середовище збагачення (Lenchenko, 2006). Установлено перевагу методу «холодового збагачення» над традиційними методами ізоляції культур ієрсиній. За опублікованими даними Н.О. Головачової (2008), під час проведення експерименту було досліджено 160 проб біологічного матеріалу. Зі слів автора, «індикація ієрсиній за традиційними методами посівів становила 26,25\% (в умовах інкубації за температури $22^{\circ} \mathrm{C}$ ) і $21,87 \%$ - за температури $37^{\circ} \mathrm{C}$; після «холодового» збагачення і наступної інкубації за температури $22^{\circ} \mathrm{C}$ індикація ієрсиній становила $58,75 \%$, а в умовах інкубації за температури $37^{\circ} \mathrm{C}-35,0 \%$. Дослідження показали, що особливо зростала ефективність «холодового» способу під час дослідження внутрішніх органів загиблих тварин, зокрема, індикація ієрсиній в умовах витримування посівів за температури $37^{\circ} \mathrm{C}$ зросла на $37,04 \%$ порівняно із традиційним методом». Виділення ієрсиній із фекалій клінічно хворих тварин становило $68,75 \%$, а із тварин без клінічних ознак - 9,37\%, що відповідно на 42,19 і 6,25\% більше, ніж в умовах застосування традиційного методу. Ізоляція ієрсиній із дерті та готових кормів стала можливою тільки в умовах застосування «холодового збагачення», про що свідчать дослідження Берковье (Berkove, Shtaihervalt, Hyiul, Khantly-Karter, Brenner, 1984). Досить значним недоліком класичного методу холодового збагачення $є$ його тривалість терміном до 15 діб, через що бактеріологічне дослідження розтягується до 28 діб. Але суттєвим буде помітити, що остаточний діагноз визначають за результатами бактеріологічного дослідження. Уникнути проходження такого довготривалого процесу дозволяють рекомендовані для швидшого виділення та ідентифікації чистої культури Y. enterocolitica експрес-методи діагностики, які передбачають застосування «холодового удару», «теплового удару» та «лужного оброблення» (Smyrnov, 2004).

Серологічні методи дослідження під час діагностики захворювання відіграють роль первинного скринінгу і дають змогу встановити наявність циркуляції збудника ієрсиніозу в організмі. За умови отримання позитивних результатів серологічних досліджень фрахівець може проводити подальші бактеріологічні дослідження з метою ізоляції збудника і встановлення остаточного діагнозу (Shevchenko, 2013; Dotsenko, Holovachova, Simonovych, 2006; Lenchenko, 2006).

Л. Б. Івановською (2007) проведено порівняльна оцінка ефективності застосування різних серологічних методів дослідження на ієрсиніоз тварин (РА, РНГА, РЗК). Авторка паралельно дослідила «294 сироваток корів, нетелів, биків, телят, свиноматок, кнурів, кобил, лошат, овець і баранів на ієрсиніоз у РА і РНГА. Узагальнений аналіз отриманих даних виявив, що суттєвої різниці за використання цих двох серологічних реакцій для вияв- лення титрів ієрсиніозних антитіл не встановлено, в окремих випадках у РА виявлялись антитіла у сироватці, які у РНГА не встановлювали, що може бути пов'язане із різними строками інфікування тварин і виявленням різних за природою антитіл. Рівень серологічної відповіді у разі застосування гомологічної гіперімунної сироватки у РЗК порівняно із РА був значно нижчим, тому остання реакція, на думку автора, є більш чутливою і специфічною».

У багатьох випадках позитивні реакції визначали одночасно за трьома антигенами (0:9, 0:3 і 0:6.30) (Holovachova, 2008). Нині існує проблема із доступністю вітчизняних діагностичних засобів і діагностуванням у культур $Y$. enterocolitica сероварів 0:5 та 0:8, хоча ці збудники, на думку більшості дослідників, мають важливе епізоотичне та епідемічне значення (Vasylev, Zolotukhyn, Pomerantsev, 2003; Karetkyna, Yushchuk, 1999; Ivanovska, 2007).

Під час власних досліджень установлено, що одним із досить простих, економічно доцільних та інформативних методів діагностики є посів на ієрсиніозне поживне середовище, на якому бактеріальна культура росте досить швидко і специфічно. На нашу думку, найперспективнішим експрес-методом діагностики ієрсиніозу у сучасних умовах є метод Maldi-TOF (Matrix Assisted Laser Desorption ionization-Time of Flight), що дає змогу швидко і достовірно ідентифікувати видову приналежність мікроорганізмів, що базується на роботі лазеру, який пронизує культуру бактерій, підіймаючи у вакуумі специфічні білки і надаючи їм певного заряду. Як детектор використовується мас-спектрометер ToF, що аналізує спектр білків для порівняння із базою даних мікроорганізмів. Результат отримують за 1-2 дні, а на третю добу можна встановити і результати чутливості до антибактеріальних препаратів (Sydorchuk, 2007). Тому ми плануємо визначити його ефективність для діагностики кишкового ієрсиніозу.

Обговорення отриманих матеріалів. Беручи до уваги все вищезазначене, можна зробити висновок, що наявні дослідження кишкового ієрсиніозу не розкривають усі аспекти сучасних епідеміологічних та епізоотологічних проблем. Нині для виявлення Y.enterocolitica використовується багато культуральних, імунологічних і молекулярних методик. Використання агару CIC i SSDC $€$ переважним для його виділення та ідентифікації, але проведення цих методів $є$ громіздким, тривалим, ненадійним і потребує біохімічного підтвердження.

Більшість авторів описують загальні дослідження Yersinia enterocolitica за допомогою або ПЦР, або РНГА; дуже рідко простежується комплексне дослідження із використанням інноваційних тест-систем. Зокрема, ієрсиніозна інфекція $€$ не досить специфічною, під час дослідження бруцельозних антигенів дає позитивну реакцію використання тільки одного із методів дослідження, що не дає досить точного результату та не може трактуватись як остаточний.

Під час постановки діагнозу потрібно уточнювати видову приналежність серотипу. Майже відсутня інформація про випадки виникнення і діагностики хвороби у дрібних домашніх тварин, зокрема у котів. Відсутні відомості про поширення захворювання на території України 
у 2015-2020 роках. Залишився малодослідженим один із шляхів передавання інфекції, а саме під час переливання крові. Відкритим $є$ питання про економічні збитки від Yersinia enterocolitica. Крім того, не повністю дослідженою залишилася тема щодо спільності патогенних серотипів для людини і тварин. Відкритою для обговорення також $€$ тема чутливості до антибіотиків, адже різні серовари у кожному з описаних випадків давали неоднозначну реакцію на антибіотики. Y enterocolitica зазвичай чутлива (in vitro) до аміноглікозидів, левоміцетину, тетрацикліну, триметоприм-сульфаметоксазолу, піперациліну, ципрофрлоксацину та цефалоспоринів третього покоління. Ізоляти часто є стійкими до пеніциліну, ампіциліну і цефалоспоринів першого покоління. Але у разі змішаного або перехресного зараження можуть бути стійкими до вищезазначених груп антимікробних препаратів.

Перспективи подальших досліджень. Планується використати сучасні методики діагностики кишкового ієрсиніозу та оцінити їхню придатність для ветеринарної практики.

\section{Висновки.}

Аналіз літературних джерел свідчить про досить значне поширення ієрсиніозної інфекції серед тварин і людей на всій території України. Хвороба має епізоотологічне, епідеміологічне, соціальне та економічне значення.

Основним джерелом інфекції для людини слугує контамінована збудником продукція тваринництва і рослинництва, що зберігається у неналежних умовах. Не заперечується прямий контакт людини із хворими тваринами або бактеріоносіями.

Ймовірним шляхом інфікування збудником кишкового ієрсиніозу є гемотрансфузія у разі порушення умов асептики.

Досить важливе етіологічне значення для всього світу мають серовари Y. enterocolitica 0:3, 0:5 0:6.30, 0:9 та 0:8, які є патогенними як для людей, так і для тварин.

Нині відсутні як експрес-тести, так і стандартні вітчизняні діагностичні засоби для встановлення серогруп основних патогенних сероварів ієрсиній.

\section{Бібліографічні посилання:}

1. Aleksich, S. A., Shtajgerval't, Dzh., Bokemul, G., Hantli-Karter, D., Brenner D. (1987). Yersinia rohdei spr. izolirovan ot fekalij cheloveka i sobak i poverhnostnyh vod [Yersinia rohdei sp. isolated from human and dog faeces and surface water], Moskva: Zhurnal bakteriol. 37 : 327-332 (in Russian).

2. Babkin, A.F., Ivanovska, L.B. (2005). Metodychni rekomendatsii z iiersyniozu tvaryn (diahnostyka, dyferentsiina diahnostyka nespetsyfichnykh reaktsii z brutseloznymy diahnostykumamy [Methodical recommendations on animal yersiniosis (diagnosis, differential diagnosis of nonspecific reactions with brucellosis diagnostics], Sumy: metod. Rek. 26 s. (in Ukrainian).

3. Md. Latiful Bari, M. Anwar Hossain, Kenji Isshiki and Dike Ukuku (2011). Behavior of Yersinia enterocolitica in Foods [Behavior of Yersinia enterocolitica in Foods]. Journal of Pathogens. Р.13. Спосіб доступу: https://doi.org/10.4061/2011/420732

4. Berkove, Kh. A. H. (2019). Shtaihervalt Revoliutsiia v diahnostytsi- metodom (Maldi-Tof) materialy KhVmizhnarodnoi konferentsii [ Yersinia aldovae (formerly Yersinia enterocolitica - like group X2): a new type of enterobacteria isolated from aquatic ecosystems]. Ptakhivnytstvo-2019, 16-20 veresnia, 2019 roku, Truskavets, s.16 (in Ukrainian).

5. Dotsenko, V.O. (2006). Metodychni rekomendatsii po laboratornii diahnostytsi iiersynioznoi infektsii svynei [Methodical recommendations for laboratory diagnosis of Yersinia infection in pigs], metod. rek. Luhansk, $31 \mathrm{~s}$. (in Ukrainian).

6. Holovachova N. O. (2008). Rol YERSINIA ENTEROCOLITICA v shlunkovo-kyshkovii ta respiratornii patolohii svynei [The role of Yersinia enterocolitica in gastrointestinal and respiratory pathology of pigs], [Rukopys]: avtoref. dys.kand. vet. Nauk, Kharkiv, 20 s. (in Ukrainian).

7. Holovchak, H.S. (2000). Epydemyolohycheskaia kharakterystyka yersynyozov v uslovyiakh urbanyzyrovannыkh terrytoryi y usovershenstvovanye systemы эpydemyolohycheskoho nadzora [Epidemiological characteristics of yersiniosis in urbanized areas and improvement of the epidemiological surveillance system], [Rukopys] : dys. kand. med. Nauk. Kiev, s. 10-29 (in Ukrainian).

8. Hyiul, A., Khantly-Karter, H., Brenner D. D. (1984). Yersinia aldovae (formerly Yersinia enterocolitica - like group X2): a new type of enterobacteria isolated from aquatic ecosystems. Int. J. Syst. Bakteryol, 34, 166-172.

9. RosaCapita, CarlosAlonso-CallejaMiguelPrietoMaría del, CaminoGarcía-Fernández BenitoMoreno (2002). Incidence and pathogenicity of Yersinia spp. isolates from poultry in Spain. International Journal of Food microbiology, 19, 4, 23, $295-301$.

10. Ivanovska, L. B. (2007). Epizootolohichnyi monitorynh ta rozrobka serolohichnoi diahnostyky iiersyniozu tvaryn [Epizootological monitoring and development of serological diagnosis of animal yersiniosis, [Rukopys] : avtoref.dys.kand. vet. nauk : 16.00.08. Kharkiv,. - 26 s. [in Ukrainian].

11. Kavruk, L.S., Shumilov, K.V., Mel'nichenko, L.P. (2005). Metodicheskie ukazanija po laboratornoj diagnostike iersinioza zhivotnyh i obnaruzheniju vozbuditelja bolezni v mjasnom syr'e, moloke i rastitel'nyh kormah [Guidelines for laboratory diagnosis of animal yersiniosis and detection of the causative agent of the disease in raw meat, milk and plant feed]; Moskva, VUNMC 14 s. (in Russian).

12. Lenchenko, E. M. (2006). Laboratornaja diagnostika vozbuditelej iersinioza: nauchnoe izdanie [Laboratory diagnostics of pathogens of yersiniosis]; Veterinarnaja patologija. Zhurnal Praktik, 5, 4-7 (in Russian).

13. Monitoring and identification of human enteropathogenic Yersinia spp; Scientific Opinion of the Panel on Biological (2007). The EFSA Journal, 1.

14. Nielsen, B., Heisel, C., Wingstrand, A. (2010). Time of development of serological reaction to Yersinia enterocolitica O: 3 in experimentally infected pigs Veterinarian. Microbiol.

15. Rosner, B.M., Stark, K., Werber, D. Epidemiology of reported Yersinia enterocolitica infections in Germany 2001-2008. BMC Public Health, 10, 337. 
16. Shevchenko, A.A., Chernyh, O.Ju., Shevchenko, L.V. et al. (2013). Diagnostika iersiniozov zhivotnyh [Diagnosis of animal yersiniosis]; uchebnoe posobie dlja studentov vysshih uchebnyh zavedenij fakul'teta veterinarnoj mediciny po napravleniju podgotovki «Veterinarija». Kub GAU, 27 s. (in Russian).

17. Smirnov, I.V. (2004). Vozbuditel' iersinioza i blizkie k nemu mikroorganizmy [The causative agent of yersiniosis and related microorganisms]. Klin mikrobiologija i antimikrobnaja, himioterapija, Toms'k, 6, 1, 10-21 (in Russian).

18. Sidorchuk, A.A. (2007). Infekcionnye bolezni zhivotnyh [Animal infectious diseases]. Uchebniki. i ucheb. posobie, Moskva, Kolos, $16 \mathrm{~s}$. (in Russian).

19. Thibodeau, V., Frost, E.H., Quessy S. (2001). Development of ELISA procedure for detection of porcine carriers of pathogenic Yersinia enterocolitica Veterinarian. Microbiol., 2001.

20. Ceneva, G.Ja. (2001). Biologicheskie svojstva iersinij i laboratornaja diagnostika psevdotuberkuleza i iersinioza [Biological properties of Yersinia and laboratory diagnostics of pseudotuberculosis and Yersiniosis]; posobie dlja vrachej. SPb., p. 60 (in Russian).

21. Ushakov, A.V. (2013). Epizotychna ta epidemiolohichna kharakterystyka iiersynioziv [Episodic and epidemiological characteristics of yersiniosis], zhurnal veterynarna medytsyna Ukrainy. 11, 213 (in Ukrainian).

22. Vasil'ev, D.A., Zolotuhin, S.N., Pomerancev, D.A. (2003). Biologicheskie svojstva fagov Yersinia Enterocolitica [Biological properties of Yersinia Enterocolitica phages]. Veterinarija. 1, 25-28 (in Russian).

23. Yarchuk, B.la, Korniienko, L. (2001). Evoliutsiia infektsiinykh khvorob. Evoliutsiini mekhanizmy «samozberezhennia» $\mathrm{u}$ bakterii [Evolution of infectious diseases. Evolutionary mechanisms of «self-preservation» in bacteria]. Veterynarna medytsyna Ukrainy,1,18-21 (in Ukrainian).

24. Rahman, A. (2011). Yersinia enterocolitica: Epidemiological Studies and Outbreaks. Journal of Pathogens, 11. URL: http:// www.hindawi.com/journals/jpath/2011/239391/.

25. Stengel, G. (2010). Zur Diagnostik und Vorkommen von, Yersinia enterocolitica in Wasser, Zoonoses and public health. URL: http://onlinelibrary.wiley.com/doi/10.1111/j.1439-0450.1986.tb00009.x/abstract

26. Gine, F., Carniel, E., Leclerc, A. (2011). Transfusion-Transmitted Yersinia enterocolitica Sepsis, ezine, 53, 6, $583-591$. URL: https://doi.org/10.1093/cid/cir452

Truba O. A., Master of Veterinary Medicine, Sumy National Agrarian University, Sumy, Ukraine Epizootological and epidemiological aspects of intestinal Yersiniosis in Ukraine (review)

The article contains analytical data on the current epidemiological situation regarding the spread of intestinal yersiniosis among animals and humans, both abroad and in Ukraine. Based on the analysis of national and foreign scientific sources, the article presents information on the spread of yersiniosis among humans and animals. Modern approaches to the identification of pathogenic strains are characterized. A review of information and comparative characteristics of methods for detection and study of Yersinia enterocolitica. The existing methods of differentiation of pathogenic and non-pathogenic strains of $Y$. enterocolitica of different serovars are established, which can be conditionally divided into 4 groups: biological, genetic, phenotypic, immunological. Based on the data obtained and our own research, it can be argued that the most reliable research results can be obtained using only a complete combination of methods. The analysis of the data identified the main serovars of the causative agent of intestinal yersiniosis, which are pathogenic for both humans and animals. After analyzing the literature data for recent years, the territory of Ukraine can be divided into areas that correspond to three levels of damage: low, medium and high. Low incidence rate of $0.01-0.11 \%$ of cases per 100 thousand population, average level of $0.12-0.58 \%$ of cases per 100 thousand population, high level of $0.59 \%$ of cases and higher per 100 thousand population.

Although Yersinia enterocolitica is a common enteropathogen that usually causes a relatively mild course of the disease, it can be a major cause of life-threatening infection following blood transfusion and sepsis. It can also lead to severe postinfectious complications such as arthritis.

Own research has shown that one of the simplest, most economically feasible and informative methods for diagnosing yersiniosis in cats is sowing on a yersiniosis nutrient medium, on which the bacterial culture grows quite quickly and specifically.

Based on the literature data, a sample of the main complexes of the study Yersinia enterocolitica. The economic estimation of their application is carried out. Issues of human and small pet biosafety regarding the spread of intestinal yersiniosis have been raised.

Key words: intestinal yersiniosis, diagnosis, epizootology, pathology, Yersinia enterocolitica, contamination, small pets, morbidity. 